\title{
THE ROLE OF TOURISM DESTINATION AND HUMAN RESOURCES IN SUSTAINABLE TOURISM IMPLEMENTATION IN INDONESIA
}

\author{
Nyoman Surya Wijaya, S.E.,M.M. Komang Trisna Pratiwi Arcana, \\ S.ST.Par.,M.Par., M.Rech, I Wayan Eka Sudarmawan, S.ST.Par., M.M. \\ International Bali Institute of Tourism \\ ekasdr@stpbi.ac.id
}

\begin{abstract}
The development of world tourism experienced a surge in tourist arrivals both international and domestic. Developments, the share of the global tourism market and new opportunities to serve the middle class is growing rapidly. The group of potential domestic tourists are expected to ensure that tourism remains a strategic sector in the national development agenda. Indonesia is very much has a very attractive tourist destination, and Bali in particular, of course, strongly felt the impact of the surge in tourist arrivals. Readiness of Tourism Human Resources are needed to support the sustainable tourism program.
\end{abstract}

Keywords: Tourism Destinations, Human Resources Tourism and Sustainable Tourism.

\section{INTRODUCTION}

Tourism in Indonesia began to grow after more than six decades of Indonesia's independence, Indonesia only began strategically planning its tourism development around 40 years ago. While in the early stages of development stagnated during the 1970 s by internal policy barriers, adjustments to the exchange rate driven by petroleum bombs, and high costs for foreign tourists compared to visiting destinations in neighboring countries. Statistics show that in 1980 Indonesia received 562,000 international visitors. Thirty years later Indonesia welcomed 7 million international visitors in 2010. In 2014 it experienced a surge over 10 million arrivals. While world tourism demand is approaching 1 billion arrivals and the domestic tourism market continues to grow, national share in the global tourism market and new opportunities to serve the fast-growing middle class and potential domestic tourist groups are expected to ensure that tourism remains a strategic sector in the development agenda national. As international and domestic tourism continue to grow, there will be greater pressure on what in some cases has become a threat to the natural environment and a vulnerable culture. This places the need for increasing awareness and sustainable tourism practices by industry and tourists as an urgent problem.

Problem Statement

Based on background explanation, the problem in this study can be 
formulated as; how are the role of tourist destinations and human resources in Indonesia?

\section{Sustainable Tourism Review:}

National Geograpic Online defines sustainable tourism as follows:

1) Tourism that provides information. Tourists not only learn about the visit (the country / region visited) but also learn how to support the continuity of the character (the country / region visited) during their trip. So that the people visited can learn (know) that habits and things that are used to attract and be appreciated by tourists.

2) Tourism that supports the integrity (integrity) of the destination.

Visitors understand and look for businesses that can emphasize the character of tourist destinations regarding matters of architecture, cuisine, heritage, aesthetics and ecology;

3) Tourism that benefits the local community. Tourism entrepreneurs do their best to employ and train local people, buy local supplies, and use services produced by local people.

4) Tourism that protects natural resources. In this tourism, tourists are aware and trying to minimize pollution, energy consumption, water use, chemicals and lighting at night.

5) Tourism that respects culture and tradition. Tourists learn and see local procedures including using a few polite words from the local language. Local people learn how to treat / deal with tourist expectations that may be different from the expectations they have.

6) This tourism does not abuse the product. Stakeholders anticipate development pressures (tourism) and apply boundaries and management techniques to prevent the syndrome of destruction (loved to death) from tourist sites. Stakeholders work together to protect natural habitats from places of cultural heritage, interesting landscapes and local culture.

7) Emphasizes quality, not quantity.

The community assesses the success of the tourism sector not from the sheer number of visits but from the length of stay, the amount of money spent, and the quality of experience gained by tourists.

8) This tourism is a memorable trip. Satisfaction, the excitement of visitors being brought home (to their area) to be conveyed to their friends and relatives, so that they are interested in getting the same thing, this will continuously provide activities at tourist destination locations.

On the other hand, While Jamieson and Noble (2000) write down several important principles of sustainable tourism development, namely:

1) Tourism has an initiative to help the community to be able to maintain control / supervision of the development of tourism.

2) This tourism is able to provide quality labor to and from the local community and there is a close (which must be maintained) relationship between local businesses and tourism.

3) There are behavioral regulations set up for tourists at all levels (national, regional and local) based on international agreement standards. Guidelines on tourism operations, estimates of tourism impact assessments, monitoring of the cumulative impacts of tourism, and acceptable threshold changes are 
examples of regulations that must be developed.

4) There are education and training programs to improve and maintain the existing cultural heritage and natural resources.

\section{METHODOLOGY}

To solve the problem in this analysis, the author uses the Descriptive Analysis Method with a Qualitative approach. Qualitative Descriptive Analysis is one type of qualitative research. According to Whitney (1960: 160), descriptive method is the search for facts with the right interpretation. Meanwhile, according to Nazir (2005: 54), descriptive method is a method in examining the status of a group of people, an object, and a set of conditions, a system of thought, or a class of events at the present time. The purpose of this descriptive study is to make a systematic, factual and accurate description, picture or painting of the facts, the nature of the relationship between the phenomena investigated.

\section{RESULT AND DISCUSSION}

The world competition for making dollars from tourists is very strong. What will be a "winner" is a destination that utilizes the power of tourism and tourism human resources to contribute in its transition to an "eco-friendly economy characterized by low carbon, slowing climate change, friendly environment, and forms of sustainable development, and social towards sustainable tourism. In Indonesia, the government is to reach the target of 12 million foreign tourists visiting in 2016. Through the Minister of Tourism, preparing 10 Leading Tourism Destinations which will be the priority of foreign tourist visits in 2016. The ten Travel Destinations which are the main priorities are as follows:

\section{Toba Lake}

Toba Lake is a volcanic lake with a length of $100 \mathrm{~km}$ and a width of 30 kilometers located in the Province of North Sumatra, Indonesia. This lake is the Largest Lake in Indonesia and also Southeast Asia in the middle there is a volcanic island called Samosir Island. The lake which is still a mainstay of Sumatra tourism is expected in 2016 to bring in more tourists.

2. Tanjung Kelayang Beach

Belitung Island is indeed famous for its beautiful and exotic beaches. One of them is Tanjung Kelayang Beach. The beach is located in Sijuk District, $27 \mathrm{~km}$ from Tanjungpandan City. This 60-hectare beach has beautiful beach views. On this beach you can also play kayaking and snorkeling.

3. Seribu Island

Besides being known as an Island Resort, the Thousand Islands is also a Marine National Park. With an area of around 107,489 hectares and around 44 islands entered the Thousand Islands Marine National Park. Marine Park which is located in North Jakarta is expected to bring more tourists in 2016. In this place you can do snorkeling, swimming or diving activities while enjoying the views of the beach which is very exotic and amazing.

4. Tanjung Lesung Beach

Tanjung Lesung Beach is a very beautiful and amazing beach tour located in the village of Tanjung Jaya, Panimbang District, Pandeglang Regency, Banten 
Province, Indonesia. This 1,500-hectare beach offers very clean and natural white sand that is perfect for you to sunbathe, swim or do other beach sports activities. With the waves that are not too big allows you to play jetsky, snorkeling, boating or fishing.

5. Borobudur Temple

Borobudur is the largest Buddhist temple in the world, located in Magelang Regency, Central Java. The stupa-shaped temple, which was founded around the 8th century during the reign of Syailendra Dynasty, became a Tourist Visit Priority in 2016. Borobudur is a masterpiece of Indonesian Buddhist art, as an example of the culmination of achieving harmony in architectural techniques and aesthetics of Buddhist art in Java. The building was inspired by Indian dharma ideas, including stupas and mandalas, but is believed to also be a continuation of local elements; punden megalithic structures or terraced pyramids found from the prehistoric period of Indonesia. As a blend of the worship of native Indonesian ancestors and the struggle to achieve Nirvana in Buddhism.

6. Bromo, Tengger, Semeru

Bromo Tengger Semeru National Park is a national park in East Java, Indonesia, located in the administrative area of Pasuruan Regency, Malang Regency, Lumajang Regency and Probolinggo Regency. The park, which stretches from east to west around 20-30 kilometers and north-south around 40 $\mathrm{km}$, has been established since 1982 with an area of about 50,276.3 ha. The caldera boundary of the sea of sand is a steep wall, whose height is between 200-700 meters.

This national park is one of the main tourist destinations in East Java. With the direct flights of Malang-Jakarta and Malang-Denpasar, it is expected that the number of foreign and domestic tourist arrivals will increase. In addition to Mount Bromo which is the main attraction, Mount Semeru which is the highest mountain on the island of Java is the main attraction for climbers. However to get to the top of Semeru is not as easy as climbing Mount Bromo and climbers are required to get permission from the office of the national park manager in Malang.

7. Mandalika

Lombok Mandalika is a natural and original sanctuary which is one of the most unique places in the world. A place where local arts and culture are celebrated and stand as a timeless tool for learning and discovering about the culture of Lombok. Mandalika, which is in NTB, is a priority for tourists to visit. Because in this area is being built international standard resorts. Not only that, to support tourism activities, this area has also been built infrastructure that makes it easy for tourists.

8. Taman Nasional Wakatobi

Wakatobi National Park is one of 50 national parks in Indonesia, located in Wakatobi district, Southeast Sulawesi. This national park was established in 2002, with a total area of 1.39 million ha, concerning marine biodiversity, scale and condition of corals; which occupies one of the highest priority positions of marine conservation in Indonesia. In this park there is a panoramic view of the beauty of the underwater world which has 25 pieces of coral reefs. Clusters of coral reefs can be found around 112 species of 13 families located at 25 points 
along $600 \mathrm{~km}$ of coastline. In addition to the beauty that is presented by a variety of coral reefs, the park also has a variety of fish species. The richness of fish species owned by this national park are 93 species of commercial and ornamental fish consumption fish. It is not wrong if Wakatobi becomes a Priority Travel Destination in 2016 by the Government of Indonesia.

9. Morotai Island

Many people say, Morotai is 'Heaven in Eastern Indonesia'. This refers to the wealth of the underwater, with more than 25 dive sites that offer unparalleled beauty. There are Tanjung Wayabula, Dodola Point, Batu Layar Point, Tanjung Sabatai Point, to Saminyamau. Everything is extraordinarily beautiful, with clear blue waters. The marine life is infinite, living between manicured coral reefs and wreckage. The natural beauty of Morotai Island is not only reflected through the underwater, but also on the mainland. A vast expanse of white sand is ready to spoil anyone's eyes who set foot on it. Sunrise and sunset panoramas become one of the most awaited moments by tourists, who apparently still rarely come there.

10. Labuan Bajo

Labuhan Bajo is a small harbor located in East Nusa Tenggara Province, Indonesia. This place is a gateway to famous tourist objects namely Komodo Island and other islands such as Rinca Island or Pink Beach.

As a member of the G20, the Indonesian economy is turning to become one of the 10 strongest economies in 2020. The tourism sector can grow as a more significant contributor to Indonesia's economic progress. Tourism can also be the foremost environmentally friendly sector for innovative development and attracting public and private capital to flow into the low carbon, resource efficient pathway.

More than just an important foreign exchange earner, tourism, if treated in a sustainable manner, can be utilized to contribute to sustainable development and important millennial development goals through the provision of jobs and employment in urban and rural areas, spreading development to more rural areas poor and isolated, improve transportation and telecommunications corridors, create environmentally friendly jobs with decent work and skills training for women and young people who may otherwise not have these opportunities.

With abundant natural and cultural resources and significant domestic and international market potential, Indonesia faces challenges about how to use all of these assets to be more beneficial for the country and its people. Sustainable development has been established in the legal framework, but its practical implementation has not been consistent. (Menpar, 2012). While strong political support for sustainable tourism and continued growth opportunities in the market continues, the orientation of the public and private sectors towards short-term economic benefits in tourism development is a major threat. In addition, human resources in tourism and hospitality are strategic issues that will determine the quality of achieving national development goals and also in enhancing Indonesia's global competitiveness.

Because of the above constraints, past development efforts have created a balance in the sector and also an uneven distribution of benefits. Furthermore, protection of the natural environment and culture in practice is still lacking, many environmental problems related to tourism directly or indirectly directly related to environmental issues endanger the sustainability of many tourism resources and pose a threat to the destination and prosperity of the host community. Likewise, the 
informal economy, which despite its contribution and role in poverty reduction and job creation for those who are not significantly trained, is an unresolved issue in the tourism sector related to various issues concerning decent work that are environmentally friendly, social security and safety and sustainability long-term.

Sustainable tourism if planned and well managed can directly and positively contribute to the achievement of Indonesia's Millennium Development Goals, including poverty reduction, rural development, cultural and community preservation, gender equality, environmental protection, climate change mitigation and demonstrate beneficial impacts on change mitigation climate. In order to benefit from these positive links, a just economic transition is needed towards low carbon development, which does not affect climate resilience, and is environmentally friendly in Indonesia with a view to Decent Work that is environmentally friendly, including education and awareness among employers / workers, workers, host communities and tourists, with local governments at the forefront. Job creation is one of the key pillars of such a transition, and the creation of decent work worthy of the environment has great potential in the tourism sector through a variety of environmentally friendly products, environmentally friendly services, public works (public works) and buildings that environmentally friendly. Dynamic investment in a Green Economy is needed to support sustainable tourism development. Sustainable tourism development can not be separated from the existence of tourist destinations (tourist destinations). In Indonesia there are 10 Most Popular Tourist Destinations in Indonesia in 2016.

Data from the Trip Trip Advisor released a list of the most popular tourist destinations this year both domestically and internationally. For tourist attractions in Indonesia, this year is still dominated by traveling destinations on the island of Bali.

The determination of this place is based on the number of comments, reviews and shares from Trip Advisor users regarding the intended destination. Next countdown the 10 most popular tourist destinations in Indonesia in 2016 according to the traveler.

1. Ubud

Ubud is a rural area on the island of Bali. Ubud is packed for exclusive tours. The best spa center in Indonesia and one of the best in the world is in Ubud. In Ubud there is also a nature reserve which houses various animals, especially monkeys. Also not to forget that Ubud is home to villas with very charming views.

Quiet tourist destination and offers beautiful natural scenery and far from the center of the crowd.

\section{Jakarta}

Jakarta is a city that is famous for its tightness, traffic jams and floods and is not behind its pollution. But if you look deeper into the city of Jakarta, it is one of the most visited and popular cities.

Jakarta as one of the gateways of foreign tourists before exploring other regions in Indonesia. Jakarta is the Thousand Islands which is very quiet with many small islands that are very similar to the Maldives. 
In the city there are also many interesting tourist attractions starting from the Old Town area, TMII, Ancol and many more

3. Yogyakarta

The city of Yogyakarta is full of amazing architecture and thick spiritual atmosphere. Destinations also range from beaches to ancient buildings from the royal era. Jogja is a cultural center in Indonesia.

4. Bukit Lawang

Bukit Lawang is a popular tourist destination located at the end of Gunung Leuser National Park. Gunung Leuser National Park (TNGL) is a flora and fauna conservation area located in Aceh and North Sumatra Provinces. Here there is conservation from endangered animals such as orangutans and Sumatran tigers.

5. Senggigi

Senggigi Beach is as famous as Kuta Beach in Bali, but its location is on the island across the east of the Island of the Gods, precisely on the island of Lombok. Senggigi is one of the favorite dive spots of world travelers.

In this Senggigi area a traveler will find Pura Batu Bolong, a Hindu temple built on a stone arch. Senggigi Beach is also very famous for its sunset phenomenon. The sunset in Senggigi is even one of the best in Indonesia.

6. Magelang

This regency is very famous for its Borobudur Temple which is so manly and is the only largest Buddhist temple in the world. Magelang does not only sell Borobudur Temple, the regency in Central Java, which is next to Yogyakarta, also has a myriad of interesting tourist destinations including rafting of the Progo and Elo rivers, trekking Mount Merapi, and enjoying Javanese culture..

7. Bandung

Bandung is the third largest city in Indonesia which is located quite close to Jakarta being the most popular tourist destination. This area offers a complete selection of tourism ranging from shopping, culinary tours to tempting nature tourism. Lately, Bandung is indeed popular with a large selection of natural attractions. The city has a beautiful botanical garden, extensive tea plantations, and golf courses to beautiful views via Tebing Keraton.

8. Labuan Bajo

Labuan Bajo is a small fishing village located in East Nusa Tenggara. In this place there is a port that is a gateway for tourists who want to go to Komodo Island and other small islands.

In addition, the waters of Labuan Bajo are also famous for being very clear with beautiful views on the surface and in the sea. Nowadays, Labuan Bajo is being hunted by travelers both from home and abroad.

9. Kuta

Kuta area in Bali is already very well known to all corners of the world even a traveler who has never been to any place would be familiar with the name of this area. Kuta Beach is so famous and a center of concentration of world tourists who vacation in Bali. On the beach it can be very interesting for tourists to watch the perfect sunset besides swimming, surfing, or sunbathing on its beautiful beaches. There is also want residents who offer massage services on the beach or braiding hair like a reagge style. 


\section{Surabaya}

Besides being the capital of East Java province, Surabaya is also known as a modern industrial city, economic and trade center. In this city there is also a headquarters for the Indonesian Navy. If you pay attention to this city it is not right to be a natural tourist destination because almost all of its area is filled with high-rise buildings like Jakarta. Some places that are worth a visit such as bamboo forests and mangrove forests. Other destinations suitable for tourism are the Sampoerna Museum, the Submarine Monument to the Bungkul Park which is predicted as the best city park in Asia.

\section{Analysis of the Potential of the Tourism Sector to Increase Job Opportunities and Income of the People of Bali Province}

The contribution of the tourism sector to Gross Domestic Product shows that in 2007, the tourism sector contributed Rp. 338,807.2 billion which puts the tourism sector in second place after the manufacturing industry sector which contributed Rp. 538,084.6 billion. The contribution of the tourism sector continued to increase from 2004 to 2008 , with interim figures in 2008 the tourism sector contributed Rp. 363,314.0 billion towards the formation of Indonesia's Gross Domestic Product. Bali is a major tourist destination in Indonesia. Bali Province, known as the Island of the Gods or Pulau Seribu Pura, has a strategic role in the development of Indonesia, especially in the tourism sector. The tourism sector, which is expected to be one of the drivers of the national economy, is largely produced from the island of Bali. Every effort is made to maintain the existence of the island of Bali in attracting tourists to flock to the island, which is full of culture and art. As a prime mover in the development of the Balinese economy, the development of the tourism sector is directed at solving fundamental economic problems, particularly in expanding employment opportunities, expanding business opportunities, meeting people's basic needs, leveling people's income, and accelerating poverty alleviation. On the other hand, in the Province of Bali there are still various problems which cannot be resolved. Bali Province unemployment and poverty rates are still high, at 77,577 people and 229,100 people in 2007 . This is a dilemmatic condition for the Provincial Government of Bali in the midst of rapid economic growth and regional development, especially with policies prioritizing the development of Bali Province in the tourism sector. Based on the conditions above, this study aims to analyze the extent of the role of the tourism sector for the development of the Province of Bali. This is seen based on its contribution to the economy, the formation of linkages between sectors, outputs, income and employment opportunities of the community. The data used are secondary data from the central BPS and other information media. The analysis used is the inputoutput analysis of the 2007 Bali Province Input-Output Table updating using the Grimp and Microsoft Office Excel 2007 program. Based on a descriptive analysis of the Bali Province Input-Output Table in 2007 domestic transactions based on producer prices, the tourism sector has a role which is relatively large on the economic structure of the Province of Bali. This can be seen from the position of the tourism sector which ranks first for the structure of demand by 36.00 percent of total demand, household consumption by 30.75 percent of total household consumption, exports by 69.30 percent of total exports, and gross value added by 37.77 percent of the total gross value added. As for the structure of government 
consumption and tourism sector investment in the total economy of the Province of Bali, each was 15.22 percent and 8.79 percent. The tourism sector as a whole has a high (direct and direct and indirect) linkage to both the input and output user sectors, meaning this sector can be relied on to encourage other sectors both upstream and downstream. The star hotel subsector has the greatest value on direct and indirect and direct future linkages. While in the direct and direct and indirect relationship to the back, the travel bureau subsector has the greatest value. The results of an analysis of the impact of the spread of the tourism sector show that the sensitivity of the spread is greater than the coefficient of spread. This shows that the tourism sector has a greater ability to drive the growth of its downstream industry compared to the ability to encourage the growth of its upstream industry. The travel bureau subsector has the highest distribution coefficient. As for the sensitivity of deployment, the star hotel sector has the highest value. Based on the multiplier value of type I and type II output, the value of the type I output multiplier in the tourism sector is 1.5231 and type II is 1.9657 . The value of the type I multiplier in the tourism sector is 1.4783 and type II is 1.8801 . Whereas the type I labor multiplier for the tourism sector is 1.9531 and type II is 2.7533 . The travel bureau subsector has multiplier output type I and type II. From the results of the multiplier analysis of type II and type II income, the cultural attractions subsector is the tourism subsector that has the most potential to increase the income of the people of Bali Province. In the multiplier analysis of type I and type II labor, the cultural attraction subsector is able to absorb more labor for the community. Based on the results of the above research, the Government of Bali Province must carry out a balanced development of the tourism sector and other sectors. This is because the contribution of tourism to the economy of the Province of Bali is relatively large and very sensitive in absorbing labor, but the sector with the most potential to increase people's income and economic output is not from the tourism sector. The government is also expected to pay attention to the viability of tourism in order to increase the number of tourist visits by developing tourism supporting facilities and infrastructure, improving tourism services, maintaining the security conditions of the Province of Bali and increasing promotional activities.

With abundant natural and cultural resources and significant domestic and international market potential, Indonesia faces challenges about how to use all of these assets to be more beneficial for the country and its people. Sustainable development has been established in the legal framework, but its practical implementation has not been consistent. (Menpar, 2012) While strong political support for sustainable tourism and continued growth opportunities in the market continues, the orientation of the public and private sectors towards short-term economic benefits in tourism development is a major threat. In addition, human resources in tourism and hospitality are strategic issues that will determine the quality of achieving national development goals and also in enhancing Indonesia's global competitiveness.

Due to the above constraints, past development efforts have caused imbalances in the sector and also uneven distribution of benefits. Furthermore, protection of the natural environment and culture in practice is still lacking, many environmental problems related to tourism are directly or indirectly related environmental issues endanger the sustainability of many tourism resources and pose a threat to the destination and prosperity of the host community. Likewise, the 
informal economy, which despite its contribution and role in poverty reduction and job creation for those who are not significantly trained, is an unresolved issue in the tourism sector related to various issues concerning decent work that are environmentally friendly, social security and safety and sustainability long-term.

Sustainable tourism if planned and well managed can directly and positively contribute to the achievement of Indonesia's Millennium Development Goals, including poverty reduction, rural development, cultural and community preservation, gender equality, environmental protection, climate change mitigation and demonstrate beneficial impacts on change mitigation climate. In order to benefit from these positive links, a just economic transition is needed towards low carbon development, which does not affect climate resilience, and is environmentally friendly in Indonesia with a view to Decent Work that is environmentally friendly, including education and awareness among employers / workers, workers, host communities and tourists, with local governments at the forefront. Job creation is one of the key pillars of such a transition, and the creation of decent work worthy of the environment has great potential in the tourism sector through a variety of environmentally friendly products, environmentally friendly services, public works and environmentally friendly buildings. Dynamic investment in a Green Economy is needed to support sustainable tourism development.

\section{CONCLUSION}

Based on the description that has been explained previously for Indonesia, the goal of sustainable tourism development (sustainable tourism) is the main goal is the achievement of public welfare in a broad sense. The main issue of Indonesian tourism is the stakeholder mindset that emphasizes limited human resources and the formation of organized tourism institutions so that tourism performance in the sense of quantitative growth can be realized and qualitative performance must also be optimized. Leadership that works consistently and persistently follows the direction of sustainable tourism planning, with regular monitoring and evaluation to cope with the dynamics of demand and also anticipate the situation. The national tourism development plan emphasizes certain values: quality of life and identity must be placed in a long-term vision for and as a basis for directing the development agenda. A concrete guideline that complements the Strategic Plan is needed to guide the various ministries and key actors involved in tourism development. Comprehensive human resource development for the next 10-20 years is needed with a view to supporting sustainable tourism.

\section{REFERENCES}

Anonim. (2010). UU RI Nomor 10 Tahun 2009 Tentang Kepariwisataan. Kementerian Kebudayaan dan Pariwisata. Jakarta.

Badan Pusat Statistik Provinsi Bali. (2007) Input-Output Provinsi Bali.

Menpar dan Ekonomi Kreatif. 2012.Rencana Strategis Pariwisata Berkelanjutan dan Green Jobs untuk Indonesia.Jakarta

Nazir, Moh. 2005. Metode Penelitian. Cetakan 6. Bogor : Ghalia Indonesia

Whitney. F.L,1960.The Elements of Resert. Asian Eds. Osaka: Overseas Book Co. 